\title{
On Chinese Translation of English Financial News Based on Functional Translation Theory \\ Weixuan Shi ${ }^{1}$, Wenqian $\mathrm{Li}^{\mathrm{i}^{*}}$
}

${ }^{1}$ Professor in School of Foreign Languages, North China Electric Power University, NO 689 Road, North District, Baoding, Hebei, China ${ }^{2}$ Graduate Student in School of Foreign Languages, North China Electric Power University, NO 689 Road, North District, Baoding, Hebei, China

DOI: $10.36348 /$ sijll.2020.v03i09.003 $\quad$ | Received: 09.09.2020 | Accepted: 16.09 .2020 | Published: 19.09 .2020

*Corresponding author: Wenqian Li

\section{Abstract}

At present, the huge shift of people's economic concept and financial management mode propels the vigorous development of financial media. Financial news, as a special style under the news genre, is a report with regard to the latest facts and situations of economic decisions, economic activities, and economic phenomena. Undoubtedly, the quality of its translation directly influences the international communication for information, language and cultural exchange. In order to help translators obtain financial information more effectively and accurately, this article introduces the linguistic features of English financial news, which is beneficial to translate them reasonably. In addition, this article selects English news and corresponding Chinese translation texts from domestic authoritative bilingual news websites, analyzes the translation texts of English financial news under the guidance of functional translation theory. Afterwards, this article puts forward some translation strategies of English financial news from the perspective of functional translation theory, and explores the instructing role of functional translation theory in news translation at the same time. This article aims at proving the rationality and practicability of this theory, and establishing a sort of audience-oriented translation view focusing on the effect of news communication, which can provide some thoughts for the future of financial news translation practice.

Keywords: Functional translation theory, financial news, translation strategy.

Copyright @ 2020: This is an open-access article distributed under the terms of the Creative Commons Attribution license which permits unrestricted use, distribution, and reproduction in any medium for non-commercial use (NonCommercial, or CC-BY-NC) provided the original author and source are credited.

\section{INTRODUCTION}

With the deepening of reform and opening-up and the gradual advancement of economic globalization, China's rapid economic development has caught eyes of numerous international media. The amount of attention that financial reports receives in China far exceeds that of ever before, while finance, tax, trade, and other financial reports in western developed countries have already occupied the mainstream position in the western media. Especially since 2008, the global economic crisis induced by the subprime mortgage crisis in the United States has become the focus of attention. With the increasing demand for financial information, overseas financial news has become an indispensable means for China to understand the world economy and transmit the current condition of China's economy to the world. The number of English financial news has soared, and the depth of analysis has been strengthened as well. Therefore, it is necessary to probe into the Chinese translation of English financial news.

\section{LITERATURE REVIEW}

At the outset, some scholars pointed out that translation problems could not be figured out in linguistics after a critical study of "equivalence translation theory", and functional translation theory as an alternative emerged in Germany in the 1970s. A representative figure, Katharina Reiss, published Translation Criticism: The Potentials and Limitations in 1971. She first presented that translation should be evaluated according to the relationship between the functions of the source text and the target text, which is regarded as the foundation of functionalism. Soon after, Hans Vermeer (1978), a student of Reiss, pioneered the kernel theory of functionalism, that is, Skopos theory, considering translation as "a kind of purposeful behavior" and "a text produced for a certain purpose and for its target audience in the context of the target language". Priority should be given to the text function and the text acceptor throughout the translation process. On the basis of Skopos theory, Justa Holz Manttari [2] further developed the theory of functional translation and defined translation as "a complex behavior 
designed to achieve cross-cultural and cross-linguistic information conversion".

Combining text type, function, and translation methods, Katharina Reiss [3] proposed four functional text types, namely "informative text", "expressive text", "operational text" and "audio-visual media text". Among them, the main function of "informative text" is to inform the readers of the objects and phenomena in the objective world, underlining that "text type is the primary factor influencing the translator to choose appropriate methods".

In 1997, Christiane Nord presented two translation strategies: documentary translation and instrumental translation. "Documentary translation" is to reproduce the communicative situation between authors and readers in the target language, including the linguistic and cultural features of the original text. "Instrumental translation" is to treat translation as a tool for communication between the target readers and the original readers, and to convey the communicative content of the original text according to the needs of the target readers.

Financial news is a news genre, which is in line with the characteristics of informative text. Accordingly, the translation of financial news must be objective and accurate. Provided that too much literary modification is employed in the practice of financial news translation, the objectivity and accuracy of financial news will be destroyed to some extent. The prime mission of financial news translation is to consider its purpose in accompany with its own features [4].

At present, there are few theoretical studies on financial news translation in China, and only a small portion of scholars have discussed it through translation practice [5-7]. For instance, some scholars use communicative translation theory to explore the application of financial news translation [8]; some analyze the lexical composition and syntactic characteristics of English financial news [9], attempting to increase the literary expression skills of financial news translation. Nevertheless, more studies merely introduce and discuss translation skills $[10,11]$, lacking core theoretical guidance and independent views. Under the guidance of German functional translation theory, this artcle investigates the Chinese translation strategies of English financial news, and verifies the practicability and operability of functional translation theory in financial news translation through specific examples.

\section{Definition and Linguistic Features of Financial News}

For the sake of understanding and mastering the information content of financial reports timely and accurately, not only should we be equipped with certain professional knowledge, but also need to distinguish financial reports from others, and acquire rules and characteristics of language use. This part introduces the definition and linguistic features of financial news.

\section{Definition}

Benqian Li [12], a journalism professor at Fudan University, holds that "financial news is the report of the latest facts and situations concerning economic decisions, economic activities and economic phenomena". As China's middle class has grown, financial media has been promoted vigorously on account of the accumulation of employment groups in the field of finance, combined with the growth of startup and investment population, as well as the change of people's economic concepts and financial management modes.

Financial news is not as formal and logical as business contracts, nor emotional as commercial advertisements. Financial news features in timeeffectiveness and practicability. With concise and clear style, it can transmit the latest financial information, dynamic stock market, property market changes, foreign exchange rate and gold futures of major countries and regions in the world by the means of reports, reviews and dynamic news, and in the shortest time deliver to the general audience through the Internet, satellite TV and newspapers and magazines. Financial news does exert an important role in news reporting. As a consequence, under no circumstances can the role of financial news translation be ignored.

\section{Linguistic Features}

(1) Lexical features

a) Technical terms and expressions

Although many technical terms and expressions frequently appear in ordinary English vocabulary, their meanings are replaced by particular financial meanings in English financial news, such as balance (the amount of money held in an account), outstanding (of a debt remaining to be paid or dealt with), appreciation (increase in monetary value), etc.

There are also some difficult technical words in that their meanings are incomprehensible for ordinary readers, that is, only those possessing corresponding professional knowledge can understand financial news. For example, the commonly used word meaning of "harden" is to "make or become hard", whereas in financial reports (especially stock market news), it means "increase in price". Besides, the commonly used word meaning of "close" is "shut", while in financial news, it means "come to an end" (closing quotation on the exchange). If translators do not acquire the special meaning of these terms in financial reports, they may be unable to truly understand the relevant reports and information.

\section{b) Abbreviations}

There are plenty of abbreviations in English financial news to make news concise and save space, 
such as CDM (China's Clean Development Mechanism), AIG (American International Group), FDI (Foreign Direct Investment), IMF (International Monetary Fund), FTA (Free Trade Agreement).

As for a translator, it is necessary to have mastery of all kinds of abbreviations commonly used in financial news and convey them to the target language readers so as to facilitate readers' understanding.

c) Loanwords, slang, and colloquial expressions

In order to make financial reports lively and interesting, English financial news often avail of some loanwords, slang, colloquial expressions, vivid and flexible words, and certain rhetorical devices to catch readers' fancy.

For example, there are many words in European and American newspapers to describe the current financial crisis, such as financial crisis, financial turmoil, and financial tsunami, among which the latter two are more vivid. In particular, the word "tsunami" derives from Japanese, using metaphorical rhetoric to describe the extent and impact of the financial crisis with the terrible natural disaster. Other vivid words are like "floating exchange rate" (浮动汇率), “stagflation" (滞胀), “bull market”(牛市), “blue sea” (蓝海).

(2) Syntactic features

a) Simple sentence and its extension

English financial news often embraces simple sentences as the main structure, prepositional phrases, infinitive phrases and participle phrases as attributives or adverbials, and noun phrases as appositives instead of subordinate clauses to make sentences more succinct. For example:

Example 1: The ISM production index climbed to 61 in April, the highest since March 2018, from 58.3.

Translation: 美国供应管理协会的生产指数 在四月份从 58.3 上升到 61 , 这是 2018 年 3 月以来 的最高值。

In this sentence, "the highest since March 2011 " is appositive.

b) Passive voice

When the subject is not explicit, passive sentences are applicable in English financial news to ensure the accuracy of expression. The adoption of this sentence pattern can not only make the theme of English news more prominent, but also keep the stance of English news more objective.

Example 2: Obama has been flayed with headlines like 'Unmitigated disaster' and 'Barack Hussein Bush'.
Translation: 奥巴马被冠以“十足的灾难”和 巴拉克·侯赛因.布什”的称号，登上了头条新闻。

This sentence is an instance of passive voice. The two titles of Obama are placed at the end of the English sentence, which conforms to the principle of end-weight, highlights the news theme, and attracts readers' attention in the meantime.

\section{c) Quotation}

Direct quotation and indirect quotation are often used in English financial news to make the evidence realistic and persuasive.

Example 3: "Baidu is teaming up with Apple to grab more traffic volume for its wireless business."Doug said.

Translation: “为了让自己的无线业务获取更 多的流量, 百度正在和苹果公司合作。”董说。

Since Dong is an employee of Baidu company, it is more convincing to quote his words directly.

\section{Translation Strategies of Financial News Based on Functional Translation Theory \\ On the basis of functional translation theory,} financial news belongs to an informative text, and the translation type is instrumental translation. In the process of translating English financial news into Chinese, the translated text should meet the requirements of translation purpose and completely realize the translation function in the target language context. Based on the pragmatic features, translation purposes and functions of financial news, specific strategies should be flexibly applied in the translation of words, sentences, and texts.

\section{Complete correspondence of words}

Traditional translation methods are principally divided into literal translation, free translation, amplification and condensation in translation. As there are many technical terms in financial news, and in view of their precise and fixed meanings, complete correspondence of words should be adopted in translation of those terms.

For translators, it is of great difficulty to translate this kind of vocabulary in the process of English to Chinese (E-C) translation. It is improper to interpret them without real understanding and try to find another translation term at will. Instead, translators should verify one by one to confirm the accuracy and unity of the translated names.

For instance, Barclay Bank (英国巴克利银行), EU (欧洲联盟/欧盟), property trust (物业信托), financial statement(财务报表). 


\section{Free Translation}

In many cases, owing to different ways of language expression, it is essential to carry out free translation strategy in E-C translation, which can help the target language readers better understand the source text, so as to avoid misunderstanding.

When it was reported in March 2009 that the U.S Treasury Department planned to take toxic assets off bank balance sheets, CCTV (China Central Television) began to translate "to take toxic assets off bank balance sheets” into “清除银行有毒 资产” (http://www.sina.com.cn). However, due to cultural differences and lack of financial expertise, considerable number of Chinese readers did not comprehend the true meaning of “有毒资产”. Soon after, the translation of it was turned into “不良资产”. Despite the fact that many people cannot figure out what kind of assets are bad assets, this kind of free translation eliminates people's confusion and misunderstanding.

Therefore, under the premise of accuracy, it is sometimes necessary to make appropriate adaptations to transform or abandon the image of the original language with an aim to accurately convey the meaning of the original text. Here are two more examples.

Example 4: What foreign businessmen find encouraging is that ideology is no longer in the driver's seat [13].

Translation: 令外商感到鼓舞的是意识形态问题 不再左右一切了。

In this news, it seems that "in the driver's seat" does not coincide with the meaning of whole news. If the phrase is literally translated into “处于驾驶员的座 位上”, Chinese readers are unable to understand the relationship between "ideology" and "drivers" in the news. Viewed from the whole sentence, the meaning of the phrase should be extended to "be in a dominant position”. “意识形态不能再左右一切”, such a free translation can help readers better understand the meaning of the original sentence.

Example 5: Battered auto-parts makers are suddenly looking like hot plays for some of Wall Street's biggest investors. (http://www.xinhuanet.com/world/)

Translation: 惨淡经营的汽车零配件公司突然摇 身一变,成为一些华尔街富豪眼中的香饽饽。

The difficult point in translating this sentence is that the phrase "hot plays" originally means popular games. As for the literal translation “华尔街富豪眼中 的热门游戏”, it is not in line with the language habits of the target language readers. The translation version “ 眼中的香饽饽” uses a colloquial Chinese expression to express more vividly and draw readers' attention. In addition, the translation of "suddenly looking like" in the original sentence also adopts the four-character idiom “摇身一变”, which is popular and easy to understand. At the same time, it accords with the original sentence's description of the significant transformation of the auto-parts company, and can realize its language expression purpose.

\section{Conversion of Parts of Speech}

As a result of grammatical restrictions, nouns are frequently utilized in English, which can express complex content. Nominalization, commonly speaking, especially exists in social science works, official articles, newspaper reviews, legal instruments, business letters and other documents. According to statistics, the nominalization ratio of financial English and journalistic English are surpassed only by legal English, far greater than that of novels [14].

Compared with English, Chinese is more inclined to take advantage of verbs. In the process of E$\mathrm{C}$ translation, if the nouns and noun phrases in the original text can be flexibly converted into verbs in Chinese, the translation will appear authentic and conform to readers' habits. Hence, in accordance with the idiomatic usage of the target language, it is a translation skill to adopt part of speech conversion in the process of E-C financial news translation.

Example 6: The availability of cheap credit over the past five years led to an expansion in the supply of loans in social economic life and the confusion in the monetary and financial markets. (http://www.chinadaily.com.cn/language_tips/)

Translation: 过去 5 年里, 由于低成本信贷 唾手可得, 导致社会经济生活中贷款数量上涨、货 币金融市场混乱。

The main structure of this sentence is "the availability of cash credit led to an expansion", in which the subject "the availability of cash credit" is an application of nominalization, which is abstract and difficult to understand. The Chinese translation version transforms nouns into verbs, and uses the four-character idiom “唾手可得”, which is in line with the description of the original sentence, expressing the meaning that low-cost credit can be easily obtained in the original text.

Example 7: The growing Fed activity has coincided with a general widening of market spreads the difference between bid and offer prices - as the number of market participants declines. (http://cn.chinadaily.com.cn/)

Translation: 在美联储交易活动不断增加的 同时,随着市场参与者减少,市场利差（出价和要价之 间的差额）普遍扩大。 
While describing the market interest spreads, this sentence uses the noun "a general widening", but it is not clear and coherent enough to translate directly into Chinese. Therefore, the noun can be converted into a verb to turn the minor sentence into “市场利差普遍 扩大”, which is consistent with the Chinese sentence structure. And the whole sentence is adjusted to put the accompanying adverbial before the main sentence, which accords with Chinese logic.

The conversion of other parts of speech is also used in translation.

Example 8: The Teck bid is conditional on Inco abandoning the deal with Falconbridge. (http://www.kekenet.com/read/news/)

Translation: 特克一科明科公司收购的条件 是：国际镍业公司放弃与鹰桥的交易。

The main structure of this news sentence is "the Teck bid is conditional". The difficulty in translation lies in the adjective "conditional". If the main sentence is translated into “特克公司收购是有条 件的”, it is difficult to link up with the second half of the sentence and the expression is not complete either. As a consequence, adjectives are converted into nouns and appropriately adopt amplification translation technique to supplement background information. The condition here refers to “收购的条件”, which is convenient for Chinese news readers to grasp.

\section{Simplification}

E. Nida [15] believes that the most important difference between English and Chinese is hypotaxis and parataxis. English sentence construction often employs various formal means to connect words, phrases, clauses, or subordinate sentences, paying attention to overt cohesion, sentence form, structural integrity, and semantic meaning. Chinese sentences use less or even no formal connection, and lay stress on covert coherence, logical order, function and meaning.

English sentence structure can be expanded and combined by various means of connection to form complex long sentences, and this feature is particularly prominent in financial English; Chinese sentence structure is relatively scattered, but the semantic level is well arranged. Therefore, in the process of translation, "the Chinese translation of English long sentences often embraces flexible means of decomposition, division and reorganization [16]."

Example 9: Indeed, the tech world is changing so fast that it brings to mind Joseph Schumpeter's comment about the "perennial gale of creative destruction" that sweeps through economies as innovative insurgents take on entrenched incumbents. (http://www.ftchinese.com/sc/index.jsp)
Translation: 技术领域变化确实迅速，这让 人想起了约瑟夫·熊彼得有关“创造性破坏的永恒风 暴”的评论，该评论当初席卷经济界就像创新型的反 叛者挑战长久的任职者一样给经济界带来了冲击性 影响。

Although some sentences in English financial news are long, their logical order is consistent with that in Chinese. There is no need to utterly adjust the order of translation, but to break long sentences into several Chinese clauses according to the meaning group. This news sentence is made up of 34 words, including two that-clauses. The first one belongs to adverbial clause of result led by "so...that", and the second one is attributive clause explaining the result brought by the first that-clause. The meaning of the sentence works on three levels: "the tech world is changing so fast", "it brings to mind Joseph Schumpeter's comment", and "the impact brought by the comment". The Chinese translation decomposes the structure of the original text and expresses the three layers of the original text one by one. Such a translation can accurately convey the meaning of the original text and is more in line with the reading habits of Chinese readers.

Example 10: The market funk was the more troubling since a Spanish government with a lot going for it had appeared to be getting a grip. (http://www.chinadaily.com.cn/language_tips/)

Translation: 虽然西班牙政府仍需继续努力 , 但它已经开始掌控局面, 这种市场恐惧更令人感 到不安。

Division is suitable for the translation of attributive elements in English sentences. In English, the attributive is often placed after the modifier, and the extremely long modifier is a big obstacle to translation, so it is common to separate the modifier into independent elements for better translation. "With a lot going for" in the original text is an attributive, which modifies the Spanish government. The Chinese translation separates it from the subordinate sentence and places it at the beginning of the sentence, so that the expression can accord with Chinese habits.

Example 11: (1)But at their annual symposium in Jackson Hole, (2) organized by the Federal Reserve Bank of Kansas City, (3) the world's leading monetary mavens could be found (4) after dinner, (5) peering enthusiastically into telescopes set up by the local astronomy club.(http://cn.chinadaily.com.cn/)

Translation: 但是 (2)由堪萨斯城美联储组织 召开的(1)杰克逊霍尔年度研讨会上, (4)晚宴后, (3) 5)世界首席货币专家们通过当地天文学俱乐部设 置的望远镜满腔热情地凝望着天空。 
When the original sentence is complex and the logical relationship is chaotic, we can try to use the reorganization method. Under the premise of clarifying the structure of long English sentences and understanding the meaning of the original text, it is advisable to completely get rid of the word order and sentence form of the original text, and recombine the sentences. Reorganization is generally based on the time and logical relationship between the parts.

In this case, the structure of the original text is completely disorganized. In English, the attributive is used to be placed after the modifier, so in the original text, (1) Jackson Hall's annual seminar is first mentioned, and then its organizer (2). However, in Chinese, the attributive is often put in front of the modifier. Therefore, the translation should first explain the organizer (2) and then describe the annual seminar (1). In the narration of Chinese, it is a priority to put forward a certain time phrase, and then to propose what happened during the time, so put (4) "after dinner" before the subject (3).

In addition, Westerners are more accustomed to the objective mode of thinking, so there are many passive voice sentences in English. When translating into Chinese, the passive voice should be converted into the active voice. In this sentence, the passive expression "could be found" in (3) is converted into the active voice “可以发现”, and is deleted according to the meaning of the sentence, so it can be better connected with (5). The translation in the example is obtained by clarifying the meaning of the original text and the differences between English and Chinese expressions.

\section{CONCLUSION}

Based on German functional translation theory, the translation of financial news needs to be combined with the characteristics of news itself, considering its purpose, and therefore must follow specific translation principles. In order to arouse readers' interest in reading, English financial news shows its own unique characteristics in language use for the needs of professional writing. Being familiar with and understanding these linguistic features will help translators obtain financial information more effectively and accurately. The key to translation lies in the correct expression of the original meaning and the transmission of information. The richer the translator's professional knowledge and vocabulary, the stronger the language analysis ability, and the more thorough understanding of the original text. In terms of expression, skillful use of various translation techniques can profoundly and accurately reflect the essence of the original text. Further speaking, good English language ability and abundant financial professional knowledge are both indispensable, as the former is the condition and the latter is the key.

\section{REFERENCES}

1. Vermeer, H. J. (1978). A framework for a general theory of translation. Heidelberg: Heidelberg University, 67.

2. Holz-Mänttäri， J. (1984). Sichtbarmachung und Beurteilung translatorischer Leistungen bei der Ausbildung von Berufstranslatoren. Wilss + Thome eds, 176-185.

3. Reiss, K. (1989). Adequacy and Equivalence in Translation. Journal of Linguistics.

4. Zhengquan, Z. (2016). Quantitative analysis of language features of international financial news. News Front, (24): 49-51.

5. Wang, W., Wang, L., Li, Y., Liu, S., Xie, Z., \& Jing, X. (2016). Nanoscale polymer metal-organic framework hybrids for effective photothermal therapy of colon cancers. Advanced Materials, 28(42), 9320-9325.

6. Jiaojiao, L. (2017). Global financial news translation quality self-assessment practice report. Xi'an Foreign Studies University.

7. Xinxin, Q. (2019). Financial news compilation practice report from the perspective of communication science. South China University of technology.

8. Na, H. (2016). Global financial news translation practice report under the guidance of communicative translation. Tianjin University.

9. Jun, X., \& Zhengquan, Z. (2014). A corpus-based study on lexical features of Chinese versions of English financial news. Chinese Foreign Languages, 11(5): 66-74.

10. Junbo, Z. (2014). English Chinese translation of financial news. Wuhan University Press.

11. Weisheng, K., \& Jiangning, Z. (2010). Translation principles and Strategies of financial news reports. Journal of Anhui Normal University (HUMANITIES AND SOCIAL SCIENCES), 38(2):237-240.

12. Benqian, L. (2006). Financial News. Dalian: Northeast University of Finance and Economics Press.

13. Huixia, P. (2010). Business translation from English to Chinese. University of international business and Economics Press.

14. Lifeng, C. (2007). Nominalization in financial discourse and its translation. Shanghai translation, (2): 24.

15. Nida, E. (2012). Principles of Correspondence. In Venuti, L. (Ed.), The Translation Studies Reader (3rd. ed.). (pp. 141- 155). London: Routledge.

16. Shuneng, L. (1993). A comparative study of English and Chinese. Beijing: Higher Education Press. 